\title{
THE
}

\section{Partisan Sorting in the United States, 1972-2012: New Evidence from a Dynamic Analysis}

Corey Lang

University of Rhode Island, clang@uri.edu

Shanna Pearson-Merkowitz

URI, shannapm@gmail.com

Follow this and additional works at: https://digitalcommons.uri.edu/enre_facpubs

Part of the American Politics Commons, Geography Commons, and the Models and Methods

Commons

The University of Rhode Island Faculty have made this article openly available.

Please let us know how Open Access to this research benefits you.

This is a pre-publication author manuscript of the final, published article.

Terms of Use

This article is made available under the terms and conditions applicable towards Open Access Policy Articles, as set forth in our Terms of Use.

\section{Citation/Publisher Attribution}

Lang, C., \& Pearson-Merkowitz, S. (2014). Partisan Sorting in the United States, 1972-2012: New Evidence from a Dynamic Analysis. Political Geography, 48, 119-129.

Available at: http://dx.doi.org/10.1016/j.polgeo.2014.09.015

This Article is brought to you for free and open access by the Environmental and Natural Resource Economics at DigitalCommons@URI. It has been accepted for inclusion in Environmental and Natural Resource Economics Faculty Publications by an authorized administrator of DigitalCommons@URI. For more information, please contact digitalcommons-group@uri.edu. 
Forthcoming in Political Geography

\title{
Partisan Sorting in the United States, 1972-2012: New Evidence from a Dynamic Analysis
}

\author{
Corey Lang \\ University of Rhode Island \\ clang@mail.uri.edu \\ and \\ Shanna Pearson-Merkowitz \\ University of Rhode Island \\ shannapm@gmail.com
}

September 2014

\begin{abstract}
Whether Americans have "sorted" into politically like-minded counties and to what extent is hotly debated by academic and journalists. This paper examines whether or not geographic sorting has occurred and why it has occurred using a novel, dynamic analysis. Our findings indicate that geographic sorting is on the rise, but that it is a very recent phenomenon. In the 1970s and 1980s, counties tended to become more competitive, but by 1996 a pattern of partisan sorting had emerged and continued through the present. Results suggest this pattern is driven by Southern re-alignment and voting behavior in partisan stronghold counties. Lastly, we find evidence that migration can drive partisan sorting, but only accounts for a small portion of the change.
\end{abstract}

This paper is a contribution of the Rhode Island Agricultural Experiment Station (\#5403). The authors would like to thank John McTague, Laura Hussey, Seth Masket, the editor and the anonymous reviewers for their helpful comments and advice. 
For the past two decades, the presidency and both houses of Congress have been hotly contested by the two political parties in each election. Yet geographically, the United States seems to be increasingly marked by one-party locales. "Red" areas where the Democratic Party lacks any ability to compete for electoral spoils and "blue" areas where the Republican Party lacks enough electoral support to even produce viable candidates, appear by many accounts to be intensifying over time (Bishop 2008; Klinkner and Hapanowitz 2005; Myers 2013; Walker 2013).

While geographic sorting has much media appeal, if, and to what extent, the country has actually sorted is an open question. Several scholars have argued that geographic sorting is a myth (Abrams and Fiorina 2012; Klinkner 2004; Glaser and Ward 2006) at the same time as others have argued it is increasing (Bishop 2008; Bishop and Cushing 2004). What drives geographic sorting if it does exist is also an open debate (Abrams and Fiorina 2012; Bishop and Cushing 2004; Myers 2013). Thus there remain two empirical questions: has the country sorted into more geographically like-minded locations? And, if so, why has this occurred?

Scholars have pointed to forces both internal and external to the political process. On the one hand, some contend that an increase in geographic polarization is primarily due to external forces: people are increasingly choosing their neighborhoods based on criteria that correlate highly with political preferences (Tam Cho, Gimpel, and Hui 2013; Bishop 2008). This argument rests on a gradual replacement mechanism: voters from the 1970s to the present have increasingly used partisan or lifestyle criteria as part of their decision about where to live. Since only a small fragment of the population relocates between each election, this process relies on a steady movement of people who gradually sort to produce homogenous communities.

Other scholars posit that changes in the electoral make-up of the United States are due to changes in the dynamics of the political parties. First a process of "secular realignment” (e.g. Key 1959) has occurred and second, political party elites have made it much easier for the electorate to understand which party they should vote for based on pre-existing policy or ideological preferences, a process scholars label "partisan sorting” (Levendusky 2009). 
The purpose of this paper is to shed new light on these questions using new methodology and improved data. First we investigate changes in geographic polarization over the last 30 years using county level presidential voting outcomes. Second, we investigate the extent to which the change in geographic polarization is due to the migratory patterns of the electorate.

Our findings indicate that the increase in geographic polarization across counties is a much more recent phenomenon than is suggested by the extant literature and that it has occurred during a time of heightened ideological purity on the part of the party elites. Our results indicate that geographic polarization did not begin until after the 1996 election. In addition, we find that the increase in geographic partisan dispersion seems to be due both to the residential mobility of voters as well as non-mobility related factors.

Our results also uncover a fascinating story in which nearly all of the action of voting dynamics has happened in the tails of the political spectrum. This is consistent with current notions of polarization: just as already politically extreme voters are becoming more extreme in their views (Pew 2014), our results indicate that places that are already marked by an apparent absence of members of the opposition party are becoming even more politically homogenous. Moreover, we find interesting results about the effect of migrants on political competition. We find that in-migration can both increase and decrease geographic polarization even when controlling for demographic factors. However, our results suggest that for most counties partisan sorting is a larger driver of polarization than in-migration. We find no evidence that out-migration has a meaningful impact on polarization.

\section{Is the Country Sorting into More Likeminded Communities?}

The desire for social harmony is so strong that people generally rule out talking about sensitive topics that increase the likelihood of disagreement (Axelrod 1997; Huckfeldt and Sprague 1993). Linus, in the 1966 television special of Charlie Brown, perhaps said it best: "There are three things I have learned never to discuss with people: religion, politics, and the Great Pumpkin." People prefer to be among those with whom 
they feel no pressure to restrain themselves from discussing their positions on such topics (particularly the Great Pumpkin).

Homophily is a well-established social priority for most individuals (McPherson, Smith-Lovin and Cook 2001). Humans seek out environments in which they feel not just safe, but comfortable. And importantly, "the most basic source of homophily is space: We are more likely to have contact with those who are closer to us in geographic location than those who are distant” (McPherson, Smith-Lovin and Cook 2001, 429). Some authors have argued that in this search for social homophily residents of the U.S are migrating to more politically homogeneous locations. Bishop (2008) argues this using data on presidential elections by county from 1974 and 2000 and in a separate analysis 1948-2000 (Bishop and Cushing 2004).

Indeed, since these analyses were performed, further evidence has suggested that the country is becoming more geographically polarized (McKee and Teigen 2009; Myers 2013; Walker 2013). Between 2000 and 2004, Klinkner and Hapanoicz (2005) found slight increases in political segregation, although it was not evident in the most strongly partisan counties, indicating that those counties closer to the mean have started to diverge politically. And Lesthaeghe and Neidert (2009) analyze the 2008 election, and find that counties that favored one party in 2004 favored the same party in greater proportions in 2008. However, several scholars have challenged this research, asserting that geographic polarization is a myth (Fiorina Abrams and Pope 2008; also see Ansolabehere, Rodden and Snyder 2006; and Glaser and Ward 2006; Klinkner 2004). Fiorina and Abrams (2012) analyzed party registration data and found "no evidence that a geographic partisan 'big sort' like that described by Bishop is ongoing” (p. 208). Thus, the extent of geographic polarization is still in dispute. Assuming for the moment that the country has been sorting itself into more politically homogenous locations, there is an additional open question: how has this process occurred?

\section{Two Potential Causes of Geographic Polarization}

If geographic polarization has been on the rise, one possible mechanism for increased levels of political homophily is voter migration. The movement of voters from 
diverse locations to areas of more political homophily, could arguably be the causal mechanism creating the appearance of a "red and blue" America. Such a hypothesis is supported by Robinson and Noriega's (2010) study of the Rocky Mountain West. Jurevich and Plane (2012) , using states as their unit of analysis, also show that the partisanship of state electorates is a consequence of the in- and out-migration of Republicans and Democrats. Likewise, Tam Cho, Gimpel and Hui (2013) find that voters state that they take living among co-partisans into account in their housing choices on opinion surveys (also see McDonald 2011) and Hawley (2014) finds that there "is a relationship between a community's political attributes and partisan's willingness to move there” (8). However, even if people are not making partisan choices per se in their housing decisions, there could be partisan consequences as a result of moving since partisanship correlates with things like tolerance for diversity and amenity preferences. To be clear, for housing decisions to create geographic polarization, people need not intentionally seek out places in which co-partisans live. People could make decisions about where to live based on "lifestyle" criteria such as proximity to a locally owned coffee shop or organic grocery, or the "walkability" of a neighborhood. But, as long as lifestyle preferences correlate with political preferences, housing decisions can create political polarization (Hawley 2014).

Equally plausible, however, is the argument that instead of migration based geographic sorting, "partisan sorting” (Levundusky 2009) or "secular realignment” (Key 1959) has taken place. In contrast to geographic sorting models where voters move to locations where people are more likeminded, a secular realignment/partisan sorting hypothesis posits that voter mobility is unrelated to the fundamental causes of polarization. Instead, two processes occur that create the appearance of an increasingly geographically sorted electorate. First, the generational replacement following a partisan realignment has resulted in the appearance of heterogeneity in places that are ideologically homogeneous. For example, in the South, the Roosevelt administration's support of civil rights, the independent candidacy of Strom Thurmond in 1948, and the subsequent passage of the Voting Rights Act in 1965 caused a critical partisan realignment (e.g. Archer and Taylor 1981, 143-162; Webster 1992; Hood, Kidd, and Morris 2012) : white southerners who were once reliably Democratic Voters today vote 
almost uniformly Republican. However, according to Green, Palmquist and Schickler (2002) few southern Democrats shifted their party identification to the Republican Party. Instead over time, generational replacement occurred where new voters identified with the Republican Party as the older Democratic identifiers passed away. During the interim, it appeared that there was partisan heterogeneity in locations that experienced no change in the demographic or ideological make-up of its residents. For example, Webster (1992) shows that in 1948, counties in Alabama stopped voting uniformly for Democratic candidates, but it was not until 1968 that a majority of Alabama counties voted for the Republican presidential nominee. In 1965, the Voting Rights Act caused the voting population in Alabama to double. These new voters gained the franchise during a time of party change. It took several generations for new voters to align their party identification to their ideological views (Green et al 2002).

However, while much attention is paid to the partisan change that occurred in the South, the membership of the two political parties across the country have changed in ways that have produced far more ideological consistency. In the 1970s, scholars bemoaned the apparent meaninglessness of the two political parties (e.g. Wattenburg 1998), but today the parties are polarized on all major issues (Thierault 2008). This consistency among the political elite has made it much easier for new voters to choose a party identification that aligns with their ideological positions (Abramowitz and Sanders 1998; Carsey and Layman 2006). Thus, one part of the sorting process is that generational replacement has occurred so that places are now more geographically homogeneous in response to realigning events and the increased ideological clarity of the political elite. If this is the case, the appearance of politically heterogeneous counties could have been a short-term phenomenon resulting from the realignment process.

\section{Partisan Sorting or Geographic Sorting?}

Although we do not argue that the mobility thesis is without merit, we find realignment/partisan sorting theory to be the more theoretically rich explanation. While race and the "culture wars" have been discussed at length for rationales of the public's 
slow and steady move toward greater party loyalty and the heightened correlation between ideology and party identification (Layman 2001), today, there are few issues that do not clearly distinguish Republicans from Democrats, and as a result, the party labels are more akin to "brand names” that encompass a range of policy positions (Aldrich 1995).

While both theories could easily produce the type of geographic polarization that commentators have lamented, there are substantial reasons to posit that realignment/partisan sorting theories are the more likely explanations. As Abrams and Fiorina (2012) note, most people believe that they live in areas with a fair amount of political heterogeneity; thus, if people are choosing their residential location based on a preference for partisan homophily, they are, in their own opinion, not doing a good job. Second, and more importantly, politics is not a common conversation topic in the United States, except for when a high profile presidential election is taking place (Lazarsfeld et al. 1944). Moreover, Americans historically are not very politically sophisticated (Campbell, Converse, Miller, and Stokes 1960). It, therefore, seems unlikely that migrants, except a select few who are very interested in politics, would go through the trouble to learn about the political characteristics of neighborhoods and make moving decisions accordingly.

Although we find partisan sorting theory and the changes in party strategy to be the more compelling explanation for geographic polarization, there is no reason that they could not be occurring simultaneously or compounding one another. The ideological clarity of the parties increases the ability of those who stay-put residentially to vote in line with their preexisting values, just as, as a result of the increase in partisan polarization, migrants may seek out places where they can express their socio-political views without fear of rejection. Thus, it may also be that as partisan sorting has occurred, people are more likely to seek out like minded places to live.

In the next section, we examine the timeline of geographic sorting and we test the extent to which the movement of the electorate has led to a more geographically polarized America. 


\section{Hypotheses and research design}

First, we must see if geographic polarization is on the rise. We posit that it is likely that the country has begun to polarize geographically given the research to date. However, given recent studies and our expectation that geographic polarization is at least to some extent a product of the slow process of partisan sorting and secular realignment, we expect the timeline for this polarization to be a quite recent phenomenon.

Second we test which theory better explains sorting. If voter migration theory is correct, we should witness an increase in geographic polarization that happened gradually over time and is correlated with the number of people who have moved. In this case, voter mobility should increase geographic polarization across the entire timespan. Partisan sorting theory on the other hand suggests that instead of a slow and steady increase over three decades, the increase in geographic polarization may have begun in the 1990s with the culmination of the realignment caused by first race and then religion and culture (Carmines and Stimson 1989; Layman 2001).

Specifically, we expect the 1990s to be a "tipping point" due to the increased ideological clarity of the parties that culminated in this period. The Republican Revolution that corresponded with the "Contract with America" and the Christian Coalition's "Contract with the American Family" (Rozell and Wilcox 1995) was a watershed moment for the ideological clarity of the Republican Party. No longer was the Republican Party to be a "big tent”, instead various Republican-leaning groups began requiring members to vote along party lines and sign a variety of "contracts" and "pledges” (such as Grover Norquists “Taxpayer Protection Pledge”) that promised to uphold a variety of conservative policy positions. Although few Americans were aware of these documents, they changed the Republican elite's operational calculus and ushered in an era of forced ideological purity. Layman et al (2010) also find that it was in the 1990s that the level of polarization across issue positions on the part of political activists and the mass public increased dramatically. Perhaps most importantly, it was 1996 when Fox News was introduced to the country. DellaVigna and Kaplan (2007) found that the emergence of the Fox News Channel in over 9,000 towns between 1996 and 2000 increased Republican vote share in the Presidential election by up to 0.7 percentage points per town. Likewise, Hopkins and Ladd (2013) found that conservatives and 
Independents voted more heavily for the Republican candidate in towns in which Fox News was first introduced and Clinton and Enamorado (2014) find that in areas in which Fox News was rolled out, Congressional representatives became more conservative in response. Thus, we expect an increase in geographic polarization in the late 1990s due to the "Fox News effect."

Clearly stated, we expect partisan geographic polarization to begin in the 1990s due to the increase in elite cues about where people with different ideological views "fit" in the two-party system. In the 2000s, we expect there to be a further increase in geographic polarization as political elites continued to polarize (McCarthy, Poole and Rosenthal 2006) and talk radio, the internet, and cable news outlets further polarized political issues (Sobieraj and Berry 2011). Finally, the 2000s marked a turning point in the technology used by the political parties and candidate campaigns to identify voters and mobilize the "base” (Hillygus and Sheilds 2009; Magleby et al 2007), thus we expect to see an increase in geographic polarization in the 1990s and 2000s due to the perfect storm of partisan ideological clarity and campaign technological advancements. Thus, we hypothesize that even accounting for the migration of voters there will be an additional increase in geographic polarization that is not accounted for by voter mobility.

Our empirical specification examines how voting evolves dynamically for a given initial starting point. We observe vote shares at the county level, $c$, for a presidential election in every year $t$, 1972-2012. County voting data was gathered from David Leip’s atlas of presidential elections, and we restrict our analysis to the Continental United States. ${ }^{1}$ The dependent variable in our model is the four-year change in Democratic Party advantage ( $\left.\Delta d a_{c, t}\right)$ between two successive presidential elections $\left(\Delta d a_{c, t}=d a_{i, t}-\right.$ $\left.d a_{i, t-1}\right)$. Democratic Party advantage equals the share of votes received by the Democratic presidential nominee minus the share of votes received by the Republican presidential nominee. Our key explanatory variable is the base-year Democratic advantage in the county, $d a_{c, t-1} \cdot{ }^{2}$ Our basic empirical specification is:

\footnotetext{
${ }^{1}$ David Liep’s data is available at: http://uselectionatlas.org/. Admittedly, using county level data results increases measurement error. Perhaps the best way to test this hypothesis would be to use neighborhood level data. However, this problem should bias our results away from finding evidence in favor of our hypotheses.

${ }^{2}$ We have included a portion of our data in the online appendix for reference.
} 
$\Delta d a_{c, t}=\beta_{t-1} d a_{c, t-1}+\delta_{t-1}+\Delta \varepsilon_{c, t}$

Where $\delta_{t-1}$ is a year fixed effect and $\varepsilon_{c, t}$ is the error term. The year fixed effects control for changes in the popularity of the parties and candidates between one election and the next. For example, the 1972 election between Nixon and McGovern was a landslide, whereas the 1976 election between Ford and Carter was close. Between these two elections, our dependent variable will be positive for a vast majority of counties, but that is due to the relative electability of the candidates, not anything inherent to sorting. Abrams and Fiorina's criticize using presidential voting as a measure of aggregate partisanship. They argue that presidential voting is the result of short-term, candidaterelated factors and so cannot be used to assess geographic polarization. Our modelling strategy accounts for this issue.

The coefficient of interest is $\beta_{t-1}$, which measures the relationship between Democratic advantage in base year $t-1$ and the change in Democratic advantage between $t-1$ and $t$. A positive $\beta_{t-1}$ would indicate that vote shares are becoming more dispersed between election $t-1$ and $t$. On average, counties with a positive Democratic Party advantage will see the Democratic advantage increase in the next election. In contrast, counties with a negative Democratic advantage (and thus a Republican vote majority) will see Democratic advantage decrease in the next election. Thus, a positive $\beta_{t-1}$ suggests an increase in geographic polarization. A negative $\beta_{t-1}$ can indicate two things. First, it can indicate that voting patterns are reverting to the mean (e.g. becoming more heterogeneous) between election $t-1$ and $t$. A county with a positive Democratic advantage would be expected to have less of a Democratic advantage in the next election. Reversion in this case, indicates that the county became more competitive. Second, a negative $\beta_{t-1}$ can indicate party switching, in which case a county with a positive Democratic advantage would be expected to have a negative Democratic advantage (i.e. a majority voting for the Republican candidate) in the next election.

Our specification allows the effect of baseline ideology on changes in partisanship $\left(\beta_{t-1}\right)$ to vary in every base election year, and this is fundamental to our research question. We are investigating not only whether or not geographic polarization has occurred, but how polarization dynamics have changed over time. 
To build intuition, we first present an example of the experience of several counties. Figure 1 plots election results for four counties, each demonstrating a different dynamic pattern. The $\mathrm{x}$-axis in each graph is the Democratic advantage in vote shares, deviated from the national average, which are the residuals from Equation (1). DeKalb County has a Republican majority in 1972, but then a Democratic majority in 1976. This would imply that $\beta_{1972}$ is negative. The Democratic majority becomes slightly stronger in 1980 , which would imply $\beta_{1976}$ is positive. The Democratic majority lessens (becomes more heterogeneous), in 1984, which would imply $\beta_{1980}$ is negative. Then the Democratic majority steadily and consistently increases through 2012, implying $\beta_{1984}$ through $\beta_{2008}$ are positive. Howard County becomes more politically diverse between 1972 and 1976, switches parties between 1976 and 1980, becomes more heterogeneous between 1980 and 1984, and then switches parties in four consecutive elections. Starting in 2000, the county is reliably Democratic and becomes increasingly so in each election. This trend would suggest that for Howard County $\beta_{1972}$ through $\beta_{1996}$ are negative and $\beta_{2000}$ through $\beta_{2008}$ are positive. Pasco County has a qualitatively similar dynamic path to Howard County in that there are many years of party switching and reversion to the national mean (negative $\beta$ ) followed by a stark shift toward one party (positive $\beta$ ). In contrast, Woodbury County becomes more heterogeneous or switches parties every election except one. DeKalb, Howard and Pasco all exhibit a dynamic pattern that foreshadows our main results: early elections were marked by an increase in heterogeneity or party switching, but later geographic sorting became the norm.

[Figure 1 about here]

To control for other factors influencing the four-year change in Democratic Party advantage, we additionally include changes in other demographic variables, $\Delta \boldsymbol{X}_{c, t}$, and state by year fixed effects, $\delta_{\bar{c}, t-1}$, where $\bar{c}$ indicates a collection of counties in the same state:

$\Delta d a_{c, t}=\beta_{t-1} d a_{c, t-1}+\Delta \boldsymbol{X}_{c, t} \gamma_{t}+\delta_{\bar{c}, t-1}+\Delta \varepsilon_{c, t}$

Demographic controls include the log of average income, log of total population, percent black, percent Hispanic, percent college graduate, percent over 65 years old, and percent male. All controls were gathered from the decennial Census except income which was 
gathered from Bureau of Economic Analysis. ${ }^{3}$ The full results of the models including the controls can be found in the online appendix.

The coefficient on the vector of changes in demographic variables is subscripted by time, to allow the influence of these variables to change over time. Again, state-year fixed effects act to control for the relative popularity of candidates, but at a state level. We estimate Equation (2) using weighted least squares, with weights equal to the total number of votes cast for each county in the base-year. Since we are interested in voting behavior and changes therein, we weight more heavily areas with more votes. ${ }^{4}$

In order to investigate if geographic movement factors into voting dynamics, we develop an extension of our model that examines how county level migration may drive geographic polarization. For this analysis, we obtained migration data from the IRS. ${ }^{5}$ This data provides a count of the number of people moving into and out of each county and the number of people who have not moved. It is available for all U.S. counties for Tax Filing Years 1990 through 2011 (e.g. Robinson and Noriega 2010). For each election beginning with 1992, we first calculated the proportion of in- and out-migrants to nonmigrants for each county for each year. Second, we aggregated these numbers for the four years preceding each election. Third, we calculated first-differences to get the change in in- and out-migration between consecutive elections. ${ }^{6}$ Finally, we estimated a variation of Equation (2), which interacts in- and out-migration with Democratic advantage, as well as controlling for in- and out-migration:

$$
\begin{aligned}
\Delta d a_{c, t} & =\beta_{t-1} d a_{c, t-1}+\theta_{t-1} \Delta i m_{c, t}+\pi_{t-1} d a_{c, t-1} \times \Delta i m_{c, t} \\
& +\mu_{t-1} \Delta o m_{c, t}+\rho_{t-1} d a_{c, t-1} \times \Delta o m_{c, t}+\Delta \boldsymbol{X}_{c, t} \gamma_{t}+\delta_{\bar{c}, t-1}+\Delta \varepsilon_{c, t}
\end{aligned}
$$

\footnotetext{
${ }^{3}$ For demographics generated from the census, linear interpolation between decade bookends was used to get values for all intra-decade elections, i.e. 1972 values were imputed from 1970 and 1980 censuses. For example, if percent black was 10\% in 1970 and 20\% in 1980, then the imputed value for 1972 would be $12 \%$ and the imputed value for 1976 would be $16 \%$. For the year 2012, we again used linear interpolation to extend the trend from 2000 to 2010 out two more years. Due to changes in the census in 2010, education data was unavailable for that year. For this year, we used the American Community Survey 5-year 2007-2011 estimates.

${ }^{4}$ Without weights, our results are qualitatively identical, but there are some changes in coefficient magnitudes and significance levels.

${ }^{5}$ Available at: http://www.irs.gov/uac/SOI-Tax-Stats-Migration-Data

${ }^{6}$ For the 1992 and 2012 elections, a full four years of migration are not available for the variable construction; we see no reason that this will bias the result.
} 
where $\Delta i m_{c, t}$ is the change in the proportion of in-migrants into county $c$ between election $t$ and $t-1$ and $\Delta o m_{c, t}$ is the change in the proportion of out-migrants into county $c$ between election $t$ and $t-1$. In Equation (3), $\theta(\mu)$ measures the impact of increases or decreases of in-migration (out-migration) rates on the change in Democratic advantage. The parameters of interest, however, are $\pi$ and $\rho$, which examine how changes in in- and out-migration, respectively, may affect changes in Democratic advantage differentially depending on the base year partisanship of the county. A negative $\pi(\rho)$ would indicate that increased in-migration (out-migration) is a force of political heterogeneity, and a positive $\pi(\rho)$ would indicate that increased in-migration (out-migration) is leading to an increase in polarization. In Equation (3), the total effect of baseline Democratic advantage is now a function of in- and out-migration rates:

$\frac{\partial \Delta d a_{c, t}}{\partial d a_{c, t-1}}=\beta_{t-1}+\pi_{t-1} \Delta i m_{c, t}+\rho_{t-1} \Delta o m_{c, t}$

We will use this Equation (4) to determine the relative importance of baseline sorting compared to in- and out-migration.

Because the IRS data are available only from 1990, we supplement this analysis using Decennial Census data 1970-2000. Due to the elimination of the long-form in the Census in 2010, this variable is only available through the 2000 election. ${ }^{7}$ From each Decennial Census, we collect data on the percentage of the each county's population that moved into the county in the last five years. We then linearly interpolate this variable to each election year and first-difference it to get $\Delta i m_{c, t}$.

\section{Results}

This section presents our empirical results. It starts by discussing the results of estimating Equation (2) on the entire set of counties in the continental United States. Then we examine if and how the patterns of voting dynamics observed for the nation as a whole are different when we split the sample by population density, partisan advantage and region.

\footnotetext{
${ }^{7}$ At least one of the reasons for the elimination of the long form was because the Census was getting the same information from the American Community Survey. However, because ACS is collected over five years, we do not get the same precision of data to match to other timereferenced data. The ACS also offers one year estimates, but these are noisy estimates given the level of imputation.
} 
Table 1 presents our main results that examine the effects of Democratic advantage on the change in Democratic advantage. Coefficients are initially negative and statistically significant through base year 1984, then transition to insignificant in base years 1988 and 1992. In base year 1996 the coefficients transition to being positive and significant and remain so through base year 2008. These results suggest that in the 1970s and most of the 1980s, party preferences tended to become more heterogeneous between elections. Then in the late 1980s and early 1990s, voter preferences showed little change. Lastly, starting in 1996 and continuing through the present, the voting dynamics shifted and voters' preferences dispersed, leading to increased geographic polarization.

[Table 1 about here]

While the pattern is clear, negative shifting to positive, we now consider the magnitude of coefficients to explain the results more thoroughly. Consider the coefficient on base year 1972, which is -0.136. This is interpreted as follows: a one percent increase in 1972 Democratic advantage is associated with a .136 percent decrease in Democratic advantage in 1976. Suppose a county votes $60 \%$ for the Democrat and $40 \%$ for the Republican, yielding a Democratic advantage of 20. Our model predicts that on average this county will reduce its Democratic advantage by $2.72 \%(=20 *-0.136)$ and the vote split will be $58.64 \%$ for Democrats and $41.36 \%$ for Republicans in 1976. Similarly, this coefficient suggests that a county with $60 \%$ of votes for the Republican candidate in 1972 will vote 58.64\% for Republicans. As the size of the advantage grows, so does the change. A county with a Republican vote share of $70 \%$ (Democratic advantage of -40) will experience a change double in magnitude to the county with a vote share of $60 \%$ Republican and is predicted to have a $67.28 \%$ Republican vote share in 1976. In contrast, the model results predict that a county with a Republican vote share of $70 \%$ in 1996 will have a Republican vote share of 71.24\% in 2000. Further, this will have a cumulative effect as all coefficients after 1996 are positive. This example county will have Republican vote shares of 72.13\%, 72.55\%, and 74.13\% in 2004, 2008 and 2012, respectively.

In sum, Table 1 offers evidence of voting polarization, but only following 1996. Following 1972, until 1984, we find consistent evidence that on average, counties became more heterogeneous or switched parties following each election. However, there was a sharp change following the 1996 election. After 1996, the results suggest that on average counties began to polarize and this polarization increased in each election thereafter. Importantly, these results are 
found while controlling for socioeconomic and other demographic changes, which capture homophily seeking behavior, and state-by-year fixed effects, which ensure that a single state or region is not driving the results. Complete model output, including coefficients on demographic variables, are available in the online appendix.

\section{Voting dynamics split by population density}

Table 2 presents an extension of Table 1 in which we examine the voting dynamics for urban, suburban and rural counties separately. There has been some speculation that the development of the suburbs and exurbs (e.g. Walks 2006) have been driving geographic political polarization. We follow the USDA Urban-Rural Continuum codes to assign counties to one of the three categories. Counties are defined as suburban if they are not urban but are proximate to an urban county and are defined as rural if they are neither urban nor proximate to an urban county. The results suggest voting evolved similarly across areas with differing population density. In all cases, we see the general pattern that counties became more competitive in the 1970s and early 1980s and then in the more recent elections, became more politically homogeneous. ${ }^{8}$

\section{[Table 2 about here]}

One interesting difference is that the shift to polarization happens slightly earlier in urban areas. For urban areas, the first positive and significant coefficient is for base year 1996 (0.08). However, the coefficients in the suburban and rural areas for base year 1996 are both insignificant. In base year 2000, suburban and rural areas have positive and significant coefficients (0.06 and 0.02, respectively). The following base year, the rural coefficient increases in magnitude to 0.07, which is in line with the magnitude seen in 1996 for urban areas and 2000 for suburban areas. Thus the results suggest that the polarizing trend spread from urban to rural density areas with some time lag. In the most recent election, each of the three types of areas showed homogenization of very similar magnitude.

\section{Voting dynamics split by partisan dominance}

\footnotetext{
${ }^{8}$ We also examined models with counties divided purely by population density or total population, instead of USDA's classification; the results were similar.
} 
Table 3 presents a second extension of Table 1 in which we examine the voting dynamics for counties that lean heavily toward a party and those that are highly competitive separately. We partition county-year observations by base election year outcomes. Counties with a Democratic advantage greater than 0.4 standard deviations above the mean for that year are labeled Democratic. Counties with a Democratic advantage less than 0.4 standard deviations below the mean vote share for that year are labeled Republican. The remaining counties are labeled competitive. We chose 0.4 standard deviations to roughly split the population of counties into thirds, while still allowing for an absolute standard, rather than relative party dominance. For example, for base election year 2000, the ranges of Democratic advantage for the Republican stronghold, competitive and Democratic stronghold, respectively, are [-86.2, -10.1], [-10.0, 11.0], and [11.2, 81.0]. For less competitive elections, these ranges shift one way or the other. [Table 3 about here]

The results of Table 3 suggest that Democratic and Republican-leaning counties had similar voting dynamics to each other and to the pattern observed in Table 1. For base years 1972 through 1992, coefficients are either negative and significant or insignificant, indicating that when voting preferences changed, they became more heterogeneous. The pattern over this time span is much stronger for Republican counties with all but one coefficient being statistically significant, versus four of six being insignificant in the Democratic group. Starting in 1996 for Democratic-leaning counties and 2000 for Republican-leaning counties, we see the coefficients become positive and significant (except for 2004 in Democratic counties), indicating polarization. Competitive counties do not show much of any trend. Consistent with overall trends, competitive counties become more heterogeneous for base year 1972 and begin to polarize for base year 2008. However, in the middle most coefficients are insignificant and the coefficient for base year 1976 is positive and anomalously large.

Overall, these results uncover a fascinating story. Essentially, nearly all of the action of voting dynamics has happened in the tails of the political spectrum. It is only in the most recent election (2012) where we see significant polarization in counties we consider "competitive." This is consistent with current notions of polarization, that is, the tails are getting further from moderate, or in this case, competitive. The remarkable finding is that in the 1970s and early 1980s, the tails were more likely to move towards becoming competitive and that shift towards greater polarization is a recent development. 


\section{Voting dynamics split by geographic region}

Table 4 explores heterogeneity in voting dynamics by region of the country (East, South, Midwest, and West) to see if the trends we observe vary by region. As explained above, there is reason to believe that the South in specific could be driving the results due to the partisan realignment of the southern states (e.g. Hood et al 2013; Archer and Taylor 1981). Overall, the results suggest that each region of the U.S. followed a similar pattern of voting dynamics. For the 1970s and early 1980s, most coefficients are negative and significant matching the pattern of increased political heterogeneity/party switching during this time. Then there is a period of stasis followed in 1996 or 2000 by positive and significant coefficients. While the overall patterns are similar, there are some differences. Notably, the West has a positive, significant coefficient in base year 1980 and a negative and (barely) significant coefficient in base year 2004, both of which run counter to the prevailing patterns. Also, in 2004, the coefficient in the Midwest is negative and strongly significant. The East also has the least evidence of any change in partisan sorting. Importantly, consistent with our expectations, the region that displays the most consistent pattern of increasing heterogeneity/party switching to increasing homogeneity is the South. While we do not find that the South is driving the results, the size of the coefficients in the 1972-1988 period is the largest of any of the models and are all negative. In addition, the South appears to polarize later than the rest of the country. The coefficient for 1996 is insignificant, indicating that the shift toward greater political homogeneity did not begin until following the 2000 election.

\section{[Table 4 about here]}

Indeed, these results suggest that while the entire pattern of geographic sorting was not due to the realignment within the South, ${ }^{9}$ the Southern realignment may account for a substantial portion of the observed increase in political heterogeneity in the early period. If the increase in geographic sorting within the South is due to partisan realignment and generational replacement, then the story told by Bishop and others about the process driving geographic polarization is neither as dire nor as phenomenal as they indicate.

\footnotetext{
${ }^{9}$ Estimating the model excluding the South results in only a few substantive changes to the model. The baseline 1980 coefficient becomes positive but is not statistically significant. The baseline 2004 coefficient becomes negative and is statistically significant at $\mathrm{p}<.01$.
} 


\section{Can voter migration explain voting dynamics?}

At this point, we have not investigated why the country began to sort during these years. While there are several possible explanations for the observed patterns in dynamics, our unique data and methodology give us the ability to test the theory that the mobility patterns of voters increased geographic polarization. Here we test how much of the change in Democratic advantage is due to voter mobility (e.g. the extent to which migration into/out of a county is the driver of geographic polarization). In these models we include residential turnover data that measures the percent of the population that has moved into the county between elections. Table 5 presents an analysis for years 19722000 that uses Decennial Census data to measure population turnover. Table 6 presents similar models as estimated in Table 5, but for the years 1992-2012 using the IRS migration data. Each of these models includes demographic controls and state by year fixed effects. Again, the results of the control variables are available in the online appendix.

[Table 5 about here]

Table 5 presents the results estimating Equation (3), modified to only include measures of in-migration, which is available in the Census. Table 5, Model 1 is the basic model with no migration data restricted to 2000 and before. This model is simply a replication of the results in Table 1 but with the data ending in 2000. The second model in Table 5 includes a control for the change of in-migration to counties, which is omitted to save space, and an interaction term between Democratic Party advantage and change in in-migration. This model directly tests the mobility hypothesis. A positive coefficient on this interaction term would indicate that as inmigration to a county increases, counties become more partisan. The results do not provide support for this hypothesis. Instead, most of the coefficients are insignificant and the two coefficients that are significant (1984 and 1988) are negative which indicates that more inmigration in these periods resulted in less geographic polarization in the following election.

Table 6 presents a similar analysis using IRS data, which include both in- and outmigration. While we and many others believe migration may play an important role in driving partisan sorting, it is unclear whether in- or out-migration are equally important or in which direction the effect should be. In-migration could lead to two different scenarios. When in- 
migration is due to homogeneity seeking behavior, in-migration should lead to an increase in polarization, however, if in-migration is due to factors not correlated with partisanship such as job-seeking behavior, in-migration might lead to greater heterogeneity. In short, people coming into a county may bring new ideas or decide to settle there because of the politics of current residents. But one could also imagine people leaving if local politics are shifting against their preferences or because the area offers no job opportunities. As Gimpel (2010) notes, outmigration can have the effect of creating one party locals if the people "left behind" are predominantly members of a single party. An important contribution of employing the IRS data is being able to simultaneously and empirically test these ideas.

Again, Model 1 of Table 6 replicates the model in Table 1 limited to the years in which the IRS filing data are available. Model 2 includes a control for change in in-migration and change in in-migration interacted with Democratic advantage. Model 3 adds a control for change in out-migration and change in out-migration interacted with Democratic advantage. It is Models 2 and 3 that directly tests the mobility hypothesis, and Model 2 serves mostly to see how the coefficients on in-migration change when out-migration is added to the model.

[Table 6 about here]

The results of Table 6 paint a very different picture than those of Table 5. In both columns 2 and 3, all of the coefficients on the in-migration interaction are statistically significant, suggesting that in-migration does indeed impact voting dynamics. Further, even base years 1992 and 1996, which were insignificant in Table 5, are significant here which indicates that the greater precision of the IRS data may lead to more precise estimates. Interestingly there is not a consistent pattern to the interaction coefficients. Two coefficients (1992 and 2000) are negative suggesting that voters entering a county increased partisan heterogeneity. In base years 1996, 2004 and 2008, the coefficients are positive indicating that in-migration increases polarization in these years. We see these results as evidence that in-migration can be a force for changing polarization, both increasing and decreasing it. However, in recent years, the results suggest that in-migration primarily has been a driver of increased polarization, even when controlling for demographic factors. 
In contrast, the results suggest that out-migration does not have the same influence on polarization that in-migration does. Only one of the five coefficients on the out-migration interaction terms is significant. While this one coefficient is positive, indicating out-migration increased polarization in 2000, it is difficult to draw too many conclusions given the inconsistency.

While the focus of Table 6 is in- and out-migration, it is important to note that the coefficients on Democratic advantage remain quite similar across the three specifications. Despite controlling for in- and out-migration and interacting these terms with Democratic advantage, the base year coefficients remain large and statistically significant, indicating that above and beyond voter migration, counties became more politically homogeneous between 1996 and 2000, 2000 and 2004, and 2008 and 2012. Only the coefficient for base year 2004 loses statistical significance with the introduction of the interaction term.

While the sign of the critical interaction terms are fairly intuitive, it is important to understand the magnitudes in order to gauge the relative importance of migration compared to baseline sorting. For this we return to Equation (4). Plugging in the appropriate coefficients from Table 6 into Equation (4) and omitting the out-migration interaction due to its insignificance, for 1996 we get $\frac{\partial \Delta d a_{c, t}}{\partial d a_{c, t-1}}=0.059+0.058 * \Delta i m_{c, t}$. When the change in in-migration is $1 \%$, baseline sorting and in-migration will be approximately equal forces for polarization. For a county with Democratic advantage equal to 20 in 1996, these results predict Democratic advantage would be 21.18 in 2000 with no change in in-migration and 22.34 with a $1 \%$ change in in-migration. In actuality, the change in in-migration tends to be less than $1 \%$; the $95^{\text {th }}$ percentile of the distribution in 1996 is $0.98 \%$ and the $75^{\text {th }}$ percentile is $0.19 \%$. This means that for most counties, baseline sorting is a greater driver of polarization than in-migration. For baseline 2008, Equation (4) becomes $\frac{\partial \Delta d a_{c, t}}{\partial d a_{c, t-1}}=0.080+0.021 * \Delta i m_{c, t}$. For a county with Democratic advantage equal to 20 in 2008, these results predict Democratic advantage would be 21.60 in 2012 with no change in in-migration and 22.02 with a 1\% change in in-migration. Again, these results are suggesting that baseline sorting is a larger driver than in-migration. Further, in-migration changes between 2008 and 2012 are small: the $95^{\text {th }}$ percentile of the distribution in 2008 is 0.80\%. However, in 2004, in-migration is a larger driver of sorting than baseline shifts alone. 
Given the importance of the region-specific results in Table 4 in shaping our understanding of the South's role in the voting dynamics observed, we also tested the findings in Table 6 to see if they were driven by regional dynamics. We split the models between southern counties and non-southern counties to see if the realignment in the south and the in- and outmigration the South has experienced is driving our results. We present these results in Table 7. The coefficients on the in-migration interaction terms are the same sign for Southern and nonSouthern counties in all base years, though only three of the five coefficients in the South are statistically significant. Only in base year 2004 is the interaction coefficient positive and significant. These results indicate that in the South, the majority of the increase in geographic polarization was not due to the migratory patterns of voters. This lends support for secular realignment and partisan sorting theories. The non-Southern counties mirror the national results presented in Table 5.

[Table 7 about here]

\section{Conclusion}

In this paper we first tested the question of whether the country has become more geographically polarized over time using a dynamic analysis. Second, we explore several possible causes of the partisan sorting patterns we observe, including Southern realignment and migration.

We find evidence that the country has begun to "sort" into more polarized counties. However, we do not find evidence that the timeline of geographic sorting fits existing accounts. Instead we find evidence that until 1988 counties that swung for one party over another either became more heterogeneous or switched parties in the following election. However, following the 1996 election, something changed. With each election, counties, on average, became more homogeneous. Our results therefore suggest that partisan realignment coupled with the rancor with which the two parties have treated each other for the last 20 years (e.g. Ansolabehere and Iyengar 1997), the advent of partisan cable news, and the 1994 “Republican Revolution," have led to an increase in geographic polarization between 1996-2012. This is a normatively undesirable situation. Our results 
show that the nation saw a larger magnitude of geographic polarization between 2008 and 2012 than at any time since 1972. As a result, not only are partisans becoming increasingly distant in their approaches to policy, they are also becoming increasingly less likely to come into contact with one another. As such, our results may contribute an explanation for why voters are becoming so disdainful toward the opposition party. The Pew Research Center $(2014,5)$ reported that partisan animosity in the American electorate has “more than doubled since 1994.” Research has shown that experience with people who are politically different from oneself increases inter-group understanding (e.g. Mutz 2006). Since our results show that during this same time period, voters have been increasingly unlikely to come into contact with the other party within their county of residence, particularly in highly partisan counties, our results may explain some of the increase in partisan animosity.

On the matter of the process that led to this geographic polarization, we tested to see if voter mobility accounted for the increase in country partisanship witnessed after 1996. Our results indicate that the increase in geographic polarization witnessed after 1996 was in part due to the migratory patterns of voters. We find evidence that particularly outside the South, migration across counties was statistically correlated with a decrease in political heterogeneity in the following election. However, inside the South, we primarily find evidence that geographic polarization was not a result of in-migration.

Our analysis is in many ways a particularly difficult hurdle for the geographic polarization thesis to cross since we examine whether it is occurring even after sociodemographic characteristics have been taken into account. To be clear, we do not propose that people are necessarily intentionally picking their neighborhood based on the known partisan make-up of the residents. People may be choosing their neighborhood based solely on lifestyle choices, but these lifestyle choices are so correlated with partisanship that they have political consequences.

Thus we conclude by finding limited support for Bishop’s “Big Sort” thesis. The migration of voters has increased the rate at which counties have become more politically homogenous, but the majority of the change, according to our models has not been caused by migration across county lines. 


\section{Works Cited}

Abramowitz, A.I., \& K. L. Saunders. (1998). "Ideological Realignment in the American Electorate." The Journal of Politics 60 (3). 634-52.

Abrams, S. \& M. Fiorina. (2012)."The Big Sort That Wasn't: A Skeptical Reexamination." PS: Political Science \& Politics 45 (2). 203-10.

Aldrich, J.H. (1995). Why Parties?: The Origin and Transformation of Political Parties in America. Chicago: University of Chicago.

Ansolabehere, S. \& S. Iyengar. (1997). Going Negative. New York: The Free Press.

Ansolabehere, S., J. Rodden and J. M. Snyder Jr.(2006). “Purple America.” Journal of Economic Perspectives. 20(2). 97-118.

Archer, J.C. \& P. J. Taylor. (1981). Section and Party. New York: Research Studies Press.

Axelrod, R. (1997). “The Dissemination of Culture: A Model with Local Convergence and Global Polarization.” Journal of Conflict Resolution 41 (2). 203-26.

Bishop, B. (2008). The Big Sort: Why the Clustering of Like-minded America Is Tearing Us Apart. Boston: Houghton Mifflin.

Bishop, B. \& R. Cushing. (2004). "Response to Philip A. Klinkner's 'Red and Blue Scare: The Continuing Diversity of the American Electoral Landscape.”’ The Forum 2(2). 1-12.

Campbell, A., P. Converse, W. Miller, \& D. Stokes. (1960). The American Voter. New York: Wiley.

Carmines, E.G, \& A.J. Stimson (1989). Issue Evolution: Race and the Transformation of American Politics. Princeton: Princeton University Press.

Carsey, T.M., \& G.C. Layman. (2006). "Changing Sides or Changing Minds? Party Identification and Policy Preferences in the American Electorate." American Journal of Political Science 50 (2). 464-77.

Clinton, J.D. \& T. Enamorado. (2014). The National News Media’s Effect on Congress: How Fox News Affected Representatives in Congress. Journal of Politics. 76 (4). Available online ahead of print (no page numbers)

Dellavigna, S. \& E. Kaplan. (2007). The Fox News Effect: Media Bias and Voting. The Quarterly Journal of Economics, 122 (3). 1187-1234.

Gimpel, J.G. (2010). “Immigration, Political Realignment, and the Demise of Republican 
Political Prospects.” Center for Immigration Studies. February. Available at: http://cis.org/republican-demise.

Gimpel, J.G. \& J.E. Schuknecht. (2004). Patchwork Nation. Ann Arbor: University of Michigan Press.

Glaser, E.L. \& B.A. Ward. (2006). "Myths and Realities of American Political Geography.” Journal of Economic Perspectives 20(2). 119-144.

Green, D., B. Palmquist \& E. Schickler. (2004). Partisan Hearts and Minds. New Haven, CT: Yale University Press.

Hawley, G. (2014). Voting and Migration Patterns in the U.S. New York: Routledge.

Hillygus, D. S, \& T.G. Shields. (2008). The Persuadable Voter: Wedge Issues in Presidential Campaigns. Princeton: Princeton University Press.

Hood III, M.V., Q. Kidd \& I. Morris. (2012). The Rational Southerner: Black Mobilization, Republican Growth, and the Partisan Transformation of the American South. Cambridge: Oxford University Press.

Hopkins, D. \& J.M. Ladd. (2014). The Consequences of Broader Media Choice: Evidence from the Expansion of Fox News. Quarterly Journal of Political Science, 9 (1). 115-135.

Huckfeldt, R. \& J. Sprague. (1993). "Citizens, Contexts, and Politics," in A.W. Finifter (ed.), Political Science: The State of the Discipline II. Washington, D.C.: American Political Science Association. Pp. 281-303.

Jurevich, J.R. \& D.A. Plane. (2012). "Voters on the move: The political effectiveness of migration and its effects on state partisan composition.” Political Geography 31 (7). 429443.

Key, V.O. 1959. Secular Realignment and the Party System. Journal of Politics 21(2): 198-210.

Klinkner, P.A. (2004). " Red and Blue Scare: The Continuing Diversity of the American Electoral Landscape.” The Forum 2 (2).1-10.

Klinkner, P.A., \& A. Hapanowicz. 2005. ' Red and Blue De' ja' vu: Measuring Political Polarization in the 2004 Election." The Forum 3 (2). 1-5.

Layman, G. 2001. The Great Divide: Religious and Cultural Conflict in American Party Politics. New York: Columbia University Press.

Layman, G.C., T.M. Carsey, J.C. Green, R. Herrera, \& R. Cooperman. (2010). “Activists and Conflict Extension in American Party Politics.” American Political Science Review 104(2). 324-46. 
Lazarsfeld, P.F., B. Berelson, \& H. Gaudet. (1944). The people's choice: how the voter makes up his mind in a presidential campaign. New York: Columbia University Press.

Lesthaeghe, R., \& L. Neidert. (2009). "US Presidential Elections and the Spatial Pattern of the American Second Demographic Transition." Population and Development Review 35 (2). 391-400.

LeSage, J. and R.K. Pace. (2009). Introduction to Spatial Econometrics. Taylor and Francis Group.

Levendusky, M. (2009). The Partisan Sort: How Liberals Became Democrats and Conservatives Became Republicans. Chicago: University of Chicago.

Lewis, P., \& M. Baldassare. (2010). "The Complexity of Public Attitudes toward Compact Development: Survey Evidence from Five State." Journal of the American Planning Association 76 (2). 219-37.

Magleby, D.B., J.Q. Monson, \& K.D. Patterson, eds. (2007). Dancing Without Partners: How Candidates, Parties, and Interest Groups Interact in the Presidential Campaign. Lanham, MD: Rowman and Littlefield.

McDonald, I. (2011). "Migration and Sorting in the American Electorate: Evidence From the 2006 Cooperative Congressional Election Study". American Politics Research. 39(3). 512-533.

McKee, S. \& J.M. Teigen. (2009). "Probing the reds and blues: Sectionalism and voter location in the 2000 and 2004 U. S. presidential elections.” Political Geography 28 (8). 484-495.

McPherson, M., L. Smith-Lovin, \& J.M. Cook. (2001). "Birds of a Feather: Homophily in Social Networks." Annual Review of Sociology 27 (1). 415-44.

Myers, A. (2013). "Secular geographical polarization in the American South: The case of Texas, 1996-2010.” Electoral Studies, 32. 48-62.

Mutz, D. (2006). Hearing the Other Side. Cambridge, MA: Cambridge University Press.

Pew Research Center. (2014). "Political Polarization in the American Public.” Available at: http://www.people-press.org/files/2014/06/6-12-2014-Political-Polarization-Release1.pdf

Robinson, T., \& S. Noriega. (2010). "Voter Migration as a Source of Electoral Change in the Rocky Mountain West." Political Geography 29(1). 28-39.

Rozell, M.J., \& C. Wilcox. (1995). God at the Grass Roots: The Christian Right in the 1994 Elections. Lanham, MD: Rowman \& Littlefield. 
Sobieraj, S. \& J. Berry. (2011). "From Incivility to Outrage: Political Discourse in Blogs, Talk Radio, and Cable News." Political Communication 28(1). 19-41.

Tam Cho, W., J.G. Gimpel, \& I. Hui. (2013). "Voter Migration and the Geographic Sorting of the American Electorate Voter Migration and the Geographic Sorting of the American Electorate." Annals of the Association of American Geographers 103(4). 1-15.

Walker, K.E. (2013). "Political Segregation of the Metropolis: Spatial Sorting by Partisan Voting in Metropolitan Minneapolis-St Paul.” City \& Community 12(1). 35-55.

Walks, R.A. (2006). "The Causes of City-Suburban Political Polarization? A Canadian Case Study." Annals of the Association of American Geographers 96 (2). 390-414.

Wattenberg, Martin P. 1998. The Decline of American Political Parties, 1952-1996. Cambridge: Harvard University Press.

Webster, Gerald R. 1992. "Demise of the Solid South.” Geographical Review 82 (1): 43-55. Williamson, T. 2008. "Sprawl, spatial location and politics: How ideological identification tracks the built environment.” American Politics Research 36 (6): 903-33.

Zelinsky, Willbur, and Barrett A. Lee. 1998. "Heterolocalism: An Alternative Model of the Sociospatial Behaviour of Immigrant Ethnic Communities.” International Journal of Population Geography. 4 (4): 281-298. 
Figure 1: Democratic advantage in presidential elections for four US counties
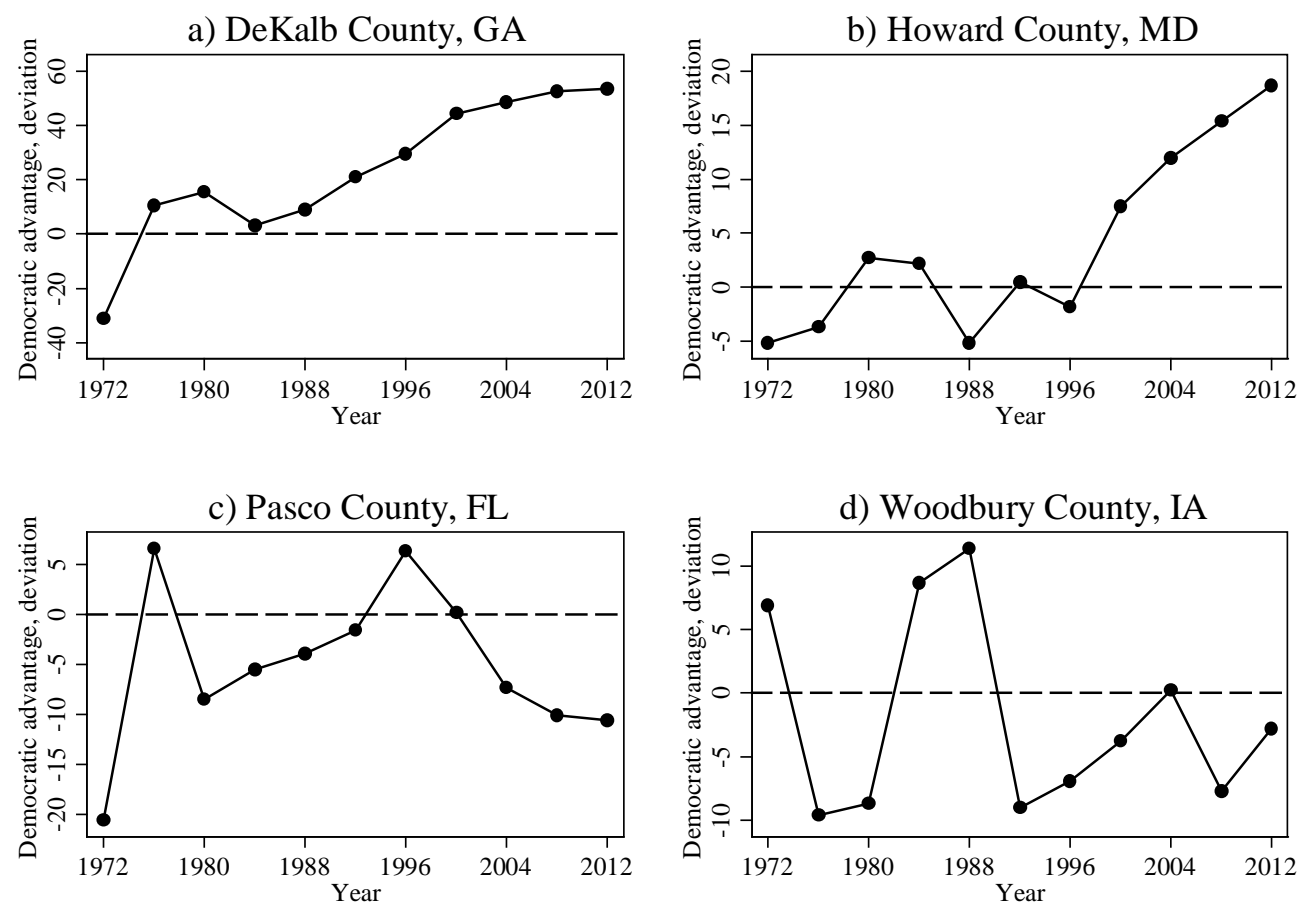

Notes: The y-axis in each graph is the Democratic advantage in vote shares, deviated from the national average. For example, DeKalb County had a Democratic advantage of 57.4\% in 2012, and the nation as a whole had a Democratic advantage of 3.8\%. The difference of $53.6 \%$ is what is plotted for the last point in the DeKalb graph. 
Table 1: The Impact of Baseline Ideology on Partisan Sorting

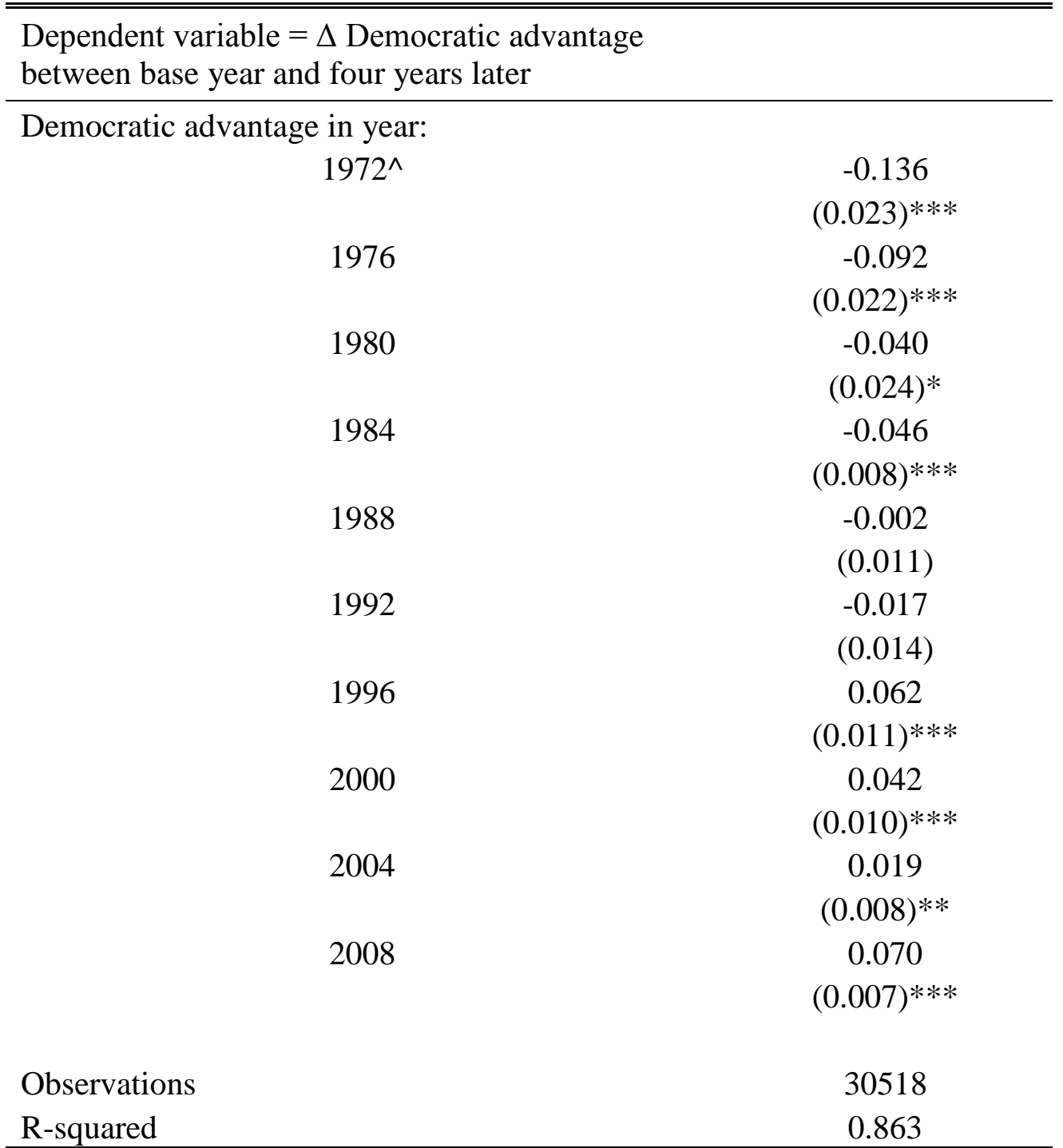

Notes: Democratic advantage equals the share of votes received by the Democratic presidential candidate minus the share of votes received by the Republican candidate. The coefficient estimates come from Equation 2, which includes demographic controls and state by year fixed effects. Demographic controls include share of population over 65, share of population with college degree, share of population male, share of population black, share of population Hispanic, log total population, and log average income. Demographic controls are first-differenced and interacted with year fixed effects to allow the effect of demographic variables to change over time. Weighted least squares is used with weights equal to total votes cast in each county-year observation. Standard errors are shown in parentheses and are estimated using the Eicker-White formula to correct for heteroskedasticity and are clustered at the county level. *,**, and *** indicate significance at $10 \%, 5 \%$, and $1 \%$, respectively.

$\wedge$ Coefficient represents the effect of Democratic advantage in 1972 on the change in Democratic advantage from 1972-1976, just as the coefficient for 2008 represents the effect of Democratic advantage in 2008 on the change in Democratic advantage from 2008-2012. 
Table 2: The Impact of Baseline Partisanship on Partisan Sorting by Population Density

\begin{tabular}{|c|c|c|c|}
\hline $\begin{array}{l}\text { Dependent variable }=\Delta \text { Democratic advantage } \\
\text { between base year and four years later }\end{array}$ & Urban & Suburban & Rural \\
\hline \multicolumn{4}{|l|}{ Democratic advantage in year: } \\
\hline \multirow[t]{2}{*}{1972} & -0.110 & -0.204 & -0.210 \\
\hline & $(0.023)^{* * *}$ & $(0.023)^{* * *}$ & $(0.024) * * *$ \\
\hline \multirow[t]{2}{*}{1976} & -0.096 & -0.081 & -0.082 \\
\hline & $(0.027)^{* * *}$ & $(0.019)^{* * *}$ & $(0.023)^{* * *}$ \\
\hline \multirow[t]{2}{*}{1980} & -0.035 & -0.057 & -0.045 \\
\hline & $(0.028)$ & $(0.022)^{* * *}$ & $(0.019)^{* *}$ \\
\hline \multirow[t]{2}{*}{1984} & -0.037 & -0.069 & -0.066 \\
\hline & $(0.009)^{* * *}$ & $(0.009) * * *$ & $(0.010)^{* * *}$ \\
\hline \multirow[t]{2}{*}{1988} & -0.000 & -0.018 & 0.004 \\
\hline & $(0.014)$ & $(0.011)$ & $(0.013)$ \\
\hline \multirow[t]{2}{*}{1992} & -0.009 & -0.071 & -0.030 \\
\hline & $(0.017)$ & $(0.013)^{* * *}$ & $(0.013)^{* *}$ \\
\hline \multirow[t]{2}{*}{1996} & 0.077 & -0.010 & -0.002 \\
\hline & $(0.013)^{* * *}$ & $(0.013)$ & $(0.013)$ \\
\hline \multirow[t]{2}{*}{2000} & 0.041 & 0.064 & 0.021 \\
\hline & $(0.012)^{* * *}$ & $(0.011)^{* * *}$ & $(0.010)^{* *}$ \\
\hline \multirow[t]{2}{*}{2004} & 0.004 & 0.069 & 0.066 \\
\hline & $(0.010)$ & $(0.011)^{* * *}$ & $(0.012)^{* * *}$ \\
\hline \multirow[t]{2}{*}{2008} & 0.067 & 0.081 & 0.081 \\
\hline & $(0.008)^{* * *}$ & $(0.007)^{* * *}$ & $(0.008) * * *$ \\
\hline
\end{tabular}


Table 3: The Impact of Baseline Partisanship on Partisan Sorting by Party Advantage

\begin{tabular}{|c|c|c|c|}
\hline $\begin{array}{l}\text { Dependent variable }=\Delta \text { Democratic advantage } \\
\text { between base year and four years later }\end{array}$ & $\begin{array}{l}\text { Democratic Party } \\
\text { Strongholds }\end{array}$ & Competitive & $\begin{array}{l}\text { Republican Party } \\
\text { Strongholds }\end{array}$ \\
\hline \multicolumn{4}{|l|}{ Democratic vote share in year: } \\
\hline \multirow[t]{2}{*}{1972} & -0.076 & -0.094 & -0.144 \\
\hline & $(0.062)$ & $(0.035)^{* * *}$ & $(0.021)^{* * *}$ \\
\hline \multirow[t]{2}{*}{1976} & -0.084 & 0.517 & -0.144 \\
\hline & $(0.037) * *$ & $(0.167)^{* * *}$ & $(0.043)^{* * *}$ \\
\hline \multirow[t]{2}{*}{1980} & 0.011 & -0.011 & -0.068 \\
\hline & $(0.059)$ & $(0.064)$ & $(0.031)^{* *}$ \\
\hline \multirow[t]{2}{*}{1984} & -0.109 & -0.024 & -0.027 \\
\hline & $(0.025)^{* * *}$ & $(0.023)$ & $(0.009)^{* * *}$ \\
\hline \multirow[t]{2}{*}{1988} & -0.041 & 0.036 & 0.023 \\
\hline & $(0.027)$ & $(0.056)$ & $(0.017)$ \\
\hline \multirow[t]{2}{*}{1992} & 0.004 & -0.013 & -0.058 \\
\hline & $(0.024)$ & $(0.049)$ & $(0.019)^{* * *}$ \\
\hline \multirow[t]{2}{*}{1996} & 0.095 & 0.062 & -0.014 \\
\hline & $(0.015)^{* * *}$ & $(0.036)^{*}$ & $(0.016)$ \\
\hline \multirow[t]{2}{*}{2000} & 0.052 & 0.040 & 0.029 \\
\hline & $(0.018)^{* * *}$ & $(0.052)$ & $(0.014)^{* *}$ \\
\hline \multirow[t]{2}{*}{2004} & -0.006 & -0.049 & 0.050 \\
\hline & $(0.014)$ & $(0.047)$ & $(0.013)^{* * *}$ \\
\hline \multirow[t]{2}{*}{2008} & 0.085 & 0.128 & 0.044 \\
\hline & $(0.011)^{* * *}$ & $(0.046) * * *$ & $(0.008)^{* * *}$ \\
\hline \multicolumn{4}{|c|}{$\begin{array}{l}\text { Notes: All coefficients shown come from a single regression, and the sample size is } 30518 \text {. Specification includes state by year fixed effects and } \\
\text { socioeconomic controls. Weighted least squares is used with weights equal to total votes cast in each county-year observation. The R-squared is } \\
0.87 \text {. For each year in the sample, counties are divided between liberal, moderate, and conservative based on where they fall in the distribution } \\
\text { of vote shares. Counties with Democratic vote shares greater than } 0.4 \text { standard deviations above the mean vote share for that year are labeled } \\
\text { Democratic Party Stronghold. Counties with Democratic vote shares less than } 0.4 \text { standard deviations below the mean vote share for that year } \\
\text { are labeled Republican Party Stronghold. The remaining counties are labeled Competitive. } 0.4 \text { standard deviations was chosen to roughly split } \\
\text { the population of counties into thirds, while still allowing for an absolute standard, rather than relative, of party strength. See Table } 1 \text { for more } \\
\text { details. }\end{array}$} \\
\hline
\end{tabular}


Table 4: The Impact of Baseline Ideology on Partisan Sorting by Region

\begin{tabular}{|c|c|c|c|c|}
\hline $\begin{array}{l}\text { Dependent variable }=\Delta \text { Democratic advantage between } \\
\text { base year and four years later }\end{array}$ & East & South & Midwest & West \\
\hline \multicolumn{5}{|l|}{ Democratic advantage in year: } \\
\hline \multirow[t]{2}{*}{1972} & -0.025 & -0.294 & -0.113 & -0.111 \\
\hline & $(0.043)$ & $(0.033)^{* * *}$ & $(0.040)^{* * *}$ & $(0.041)^{* * *}$ \\
\hline \multirow[t]{2}{*}{1976} & -0.171 & -0.068 & -0.071 & -0.016 \\
\hline & $(0.055)^{* * *}$ & $(0.027)^{* *}$ & $(0.045)$ & $(0.050)$ \\
\hline \multirow[t]{2}{*}{1980} & 0.076 & -0.148 & -0.069 & 0.083 \\
\hline & $(0.046)^{*}$ & $(0.022) * * *$ & $(0.041)^{*}$ & $(0.038) * *$ \\
\hline \multirow[t]{2}{*}{1984} & -0.047 & -0.038 & -0.080 & 0.008 \\
\hline & $(0.015)^{* * *}$ & $(0.011)^{* * *}$ & $(0.016)^{* * *}$ & $(0.022)$ \\
\hline \multirow[t]{2}{*}{1988} & -0.050 & -0.010 & 0.014 & 0.057 \\
\hline & $(0.031)$ & $(0.014)$ & $(0.018)$ & $(0.030)^{*}$ \\
\hline \multirow[t]{2}{*}{1992} & -0.033 & -0.019 & -0.048 & 0.049 \\
\hline & $(0.045)$ & $(0.013)$ & $(0.025)^{*}$ & $(0.031)$ \\
\hline \multirow[t]{2}{*}{1996} & 0.113 & 0.022 & 0.041 & 0.091 \\
\hline & $(0.026)^{* * *}$ & $(0.018)$ & $(0.013)^{* * *}$ & $(0.032)^{* * *}$ \\
\hline \multirow[t]{2}{*}{2000} & 0.001 & 0.051 & 0.045 & 0.071 \\
\hline & $(0.020)$ & $(0.016)^{* * *}$ & $(0.012)^{* * *}$ & $(0.027)^{* * *}$ \\
\hline \multirow[t]{2}{*}{2004} & 0.009 & 0.092 & -0.033 & -0.021 \\
\hline & $(0.017)$ & $(0.018)^{* * *}$ & $(0.010)^{* * *}$ & $(0.012)^{*}$ \\
\hline \multirow[t]{2}{*}{2008} & 0.093 & 0.055 & 0.099 & 0.053 \\
\hline & $(0.023)^{* * *}$ & $(0.008)^{* * *}$ & $(0.008)^{* * *}$ & $(0.013)^{* * *}$ \\
\hline
\end{tabular}

Notes: All coefficients shown come from a single regression with region dummy variables interacted with Democratic advantage. The sample size is 30518. Specification includes state by year fixed effects and demographic controls. Weighted least squares is used with weights equal to total votes cast in each county-year observation. The R-squared is 0.87 . See Table 1 for more details. 
Table 5: Voting Dynamics and Population Turnover, 1972-2000

\begin{tabular}{|c|c|c|}
\hline $\begin{array}{l}\text { Dependent variable }=\Delta \text { Democratic advantage } \\
\text { between base year and four years later }\end{array}$ & (1) & (2) \\
\hline \multicolumn{3}{|l|}{ Democratic advantage in year: } \\
\hline 1972 & $\begin{array}{c}-0.136 \\
(0.023)^{* * *}\end{array}$ & $\begin{array}{c}-0.129 \\
(0.024)^{* * *}\end{array}$ \\
\hline 1976 & $\begin{array}{c}-0.092 \\
(0.022)^{* * *}\end{array}$ & $\begin{array}{c}-0.096 \\
(0.025)^{* * *}\end{array}$ \\
\hline 1980 & $\begin{array}{c}-0.040 \\
(0.024)^{*}\end{array}$ & $\begin{array}{l}-0.032 \\
(0.024)\end{array}$ \\
\hline 1984 & $\begin{array}{c}-0.046 \\
(0.008)^{* * *}\end{array}$ & $\begin{array}{c}-0.043 \\
(0.008)^{* * *}\end{array}$ \\
\hline 1988 & $\begin{array}{c}-0.002 \\
(0.011)\end{array}$ & $\begin{array}{l}-0.006 \\
(0.012)\end{array}$ \\
\hline 1992 & $\begin{array}{l}-0.017 \\
(0.014)\end{array}$ & $\begin{array}{l}-0.018 \\
(0.014)\end{array}$ \\
\hline 1996 & $\begin{array}{c}0.062 \\
(0.011)^{* * *}\end{array}$ & $\begin{array}{c}0.067 \\
(0.011)^{* * *}\end{array}$ \\
\hline
\end{tabular}

Democratic advantage $\mathrm{X} \Delta$ share new county residents in year:

\begin{tabular}{|c|c|}
\hline 1972 & $\begin{array}{l}-0.011 \\
(0.009)\end{array}$ \\
\hline 1976 & $\begin{array}{c}0.002 \\
(0.008)\end{array}$ \\
\hline 1980 & $\begin{array}{l}-0.003 \\
(0.009)\end{array}$ \\
\hline 1984 & $\begin{array}{c}-0.013 \\
(0.004)^{* * *}\end{array}$ \\
\hline 1988 & $\begin{array}{c}-0.027 \\
(0.008)^{* * *}\end{array}$ \\
\hline 1992 & $\begin{array}{c}0.009 \\
(0.008)\end{array}$ \\
\hline 1996 & $\begin{array}{c}0.007 \\
(0.006)\end{array}$ \\
\hline
\end{tabular}

Notes: Each column represents a separate regression with state by year fixed effects and demographic controls. Column 1 replicates the results in Table 1. Column 2 presents results from a specification that additionally includes change in share of new county residents as a control as well as interacted with Democratic advantage. Share of new county residents comes from Decennial Census. See Table 1 and text for more details. 
Table 6: Voting Dynamics and Population Turnover, 1992-2012

\begin{tabular}{|c|c|c|c|}
\hline $\begin{array}{l}\text { Dependent variable }=\Delta \text { Democratic advantage } \\
\text { between base year and four years later }\end{array}$ & (1) & (2) & (3) \\
\hline \multicolumn{4}{|l|}{ Democratic advantage in year: } \\
\hline 1992 & $\begin{array}{l}-0.017 \\
(0.014)\end{array}$ & $\begin{array}{c}0.009 \\
(0.019)\end{array}$ & $\begin{array}{c}0.008 \\
(0.019)\end{array}$ \\
\hline \multirow[t]{2}{*}{1996} & 0.062 & 0.059 & 0.059 \\
\hline & $(0.011)^{* * *}$ & $(0.010)^{* * *}$ & $(0.010)^{* * *}$ \\
\hline \multirow[t]{2}{*}{2000} & 0.042 & 0.038 & 0.037 \\
\hline & $(0.010)^{* * *}$ & $(0.010)^{* * *}$ & $(0.009)^{* * *}$ \\
\hline \multirow[t]{2}{*}{2004} & 0.019 & 0.012 & 0.011 \\
\hline & $(0.008)^{* *}$ & $(0.008)$ & $(0.009)$ \\
\hline \multirow[t]{2}{*}{2008} & 0.070 & 0.081 & 0.080 \\
\hline & $(0.007)^{* * *}$ & $(0.008)^{* * *}$ & $(0.007)^{* * *}$ \\
\hline \multicolumn{4}{|c|}{ Democratic advantage $\mathrm{X} \Delta$ share new county in-migrants in year: } \\
\hline \multirow{2}{*}{\multicolumn{2}{|c|}{1992}} & -0.030 & -0.030 \\
\hline & & $(0.009)^{* * *}$ & $(0.009)^{* * *}$ \\
\hline \multicolumn{2}{|l|}{1996} & 0.050 & 0.058 \\
\hline & & $(0.009)^{* * *}$ & $(0.010)^{* * *}$ \\
\hline \multirow{2}{*}{\multicolumn{2}{|c|}{2000}} & -0.029 & -0.028 \\
\hline & & $(0.011)^{* *}$ & $(0.010)^{* * *}$ \\
\hline \multirow{2}{*}{\multicolumn{2}{|c|}{2004}} & 0.024 & 0.033 \\
\hline & & $(0.003)^{* * *}$ & $(0.011)^{* * *}$ \\
\hline \multirow{2}{*}{\multicolumn{2}{|c|}{2008}} & 0.019 & 0.021 \\
\hline & & $(0.005)^{* * *}$ & $(0.005)^{* * *}$ \\
\hline \multicolumn{4}{|c|}{ Democratic advantage $\mathrm{X} \Delta$ share new county out-migrants in year: } \\
\hline \multirow{2}{*}{\multicolumn{2}{|c|}{1992}} & & -0.024 \\
\hline & & & $(0.016)$ \\
\hline \multirow{2}{*}{\multicolumn{2}{|c|}{1996}} & & -0.024 \\
\hline & & & $(0.016)$ \\
\hline \multirow{2}{*}{\multicolumn{2}{|c|}{2000}} & & 0.039 \\
\hline & & & $(0.013)^{* * *}$ \\
\hline \multirow[t]{2}{*}{2004} & & & -0.004 \\
\hline & & & $(0.004)$ \\
\hline 2008 & & & -0.001 \\
\hline
\end{tabular}

Notes: Each column represents a separate regression with state by year fixed effects and demographic controls. Column 1 replicates the results in Table 1 . Column 2 presents results from a specification that additionally includes change in share of new in-migrants as a control as well as interacted with Democratic advantage. Column 3 presents results from a specification that additionally includes change in share of new out-migrants as a control as well as interacted with Democratic advantage. County in- and out-migrant data come from IRS migration data. See Table 1 and text for more details. 
Table 7: Voting Dynamics and Population Turnover, 1992-2012, for Southern and Non-Southern Counties

\begin{tabular}{|c|c|c|}
\hline $\begin{array}{l}\text { Dependent variable }=\Delta \text { Democratic advantage between base } \\
\text { year and four years later }\end{array}$ & South & Non-South \\
\hline \multicolumn{3}{|l|}{ Democratic advantage in year: } \\
\hline 1992 & $\begin{array}{c}0.063 \\
(0.035)^{*}\end{array}$ & $\begin{array}{c}0.002 \\
(0.021)\end{array}$ \\
\hline 1996 & $\begin{array}{c}0.058 \\
(0.036)\end{array}$ & $\begin{array}{c}0.051 \\
(0.010)^{* * *}\end{array}$ \\
\hline 2000 & $\begin{array}{c}0.059 \\
(0.026)^{* *}\end{array}$ & $\begin{array}{c}0.033 \\
(0.010)^{* * *}\end{array}$ \\
\hline 2004 & $\begin{array}{c}0.098 \\
(0.024)^{* * *}\end{array}$ & $\begin{array}{l}-0.011 \\
(0.008)\end{array}$ \\
\hline 2008 & $\begin{array}{c}0.067 \\
(0.012)^{* * *}\end{array}$ & $\begin{array}{c}0.084 \\
(0.012)^{* * *}\end{array}$ \\
\hline \multicolumn{3}{|l|}{ Democratic advantage $\mathrm{X} \Delta$ share new county in-migrants in year: } \\
\hline 1992 & $\begin{array}{c}-0.034 \\
(0.015)^{* *}\end{array}$ & $\begin{array}{c}-0.039 \\
(0.011)^{* * *}\end{array}$ \\
\hline 1996 & $\begin{array}{c}0.019 \\
(0.023)\end{array}$ & $\begin{array}{c}0.061 \\
(0.011)^{* * *}\end{array}$ \\
\hline 2000 & $\begin{array}{c}-0.047 \\
(0.022)^{* *}\end{array}$ & $\begin{array}{c}-0.028 \\
(0.013)^{* *}\end{array}$ \\
\hline 2004 & $\begin{array}{c}0.087 \\
(0.027)^{* * *}\end{array}$ & $\begin{array}{c}0.026 \\
(0.009)^{* * *}\end{array}$ \\
\hline 2008 & $\begin{array}{c}0.003 \\
(0.008)\end{array}$ & $\begin{array}{c}0.034 \\
(0.006)^{* * *}\end{array}$ \\
\hline \multicolumn{3}{|l|}{ Democratic advantage $\mathrm{X} \Delta$ share new county out-migrants in year: } \\
\hline 1992 & $\begin{array}{l}-0.018 \\
(0.032)\end{array}$ & $\begin{array}{l}-0.014 \\
(0.020)\end{array}$ \\
\hline 1996 & $\begin{array}{c}0.008 \\
(0.029)\end{array}$ & $\begin{array}{l}-0.027 \\
(0.017)\end{array}$ \\
\hline 2000 & $\begin{array}{c}0.062 \\
(0.040)\end{array}$ & $\begin{array}{c}0.047 \\
(0.014)^{* * *}\end{array}$ \\
\hline 2004 & $\begin{array}{c}-0.027 \\
(0.010)^{* * *}\end{array}$ & $\begin{array}{c}0.007 \\
(0.007)\end{array}$ \\
\hline 2008 & $\begin{array}{c}0.002 \\
(0.001)\end{array}$ & $\begin{array}{l}-0.004 \\
(0.013)\end{array}$ \\
\hline
\end{tabular}

Notes: Each column represents a separate regression with the same specification as Column 3 of Table 6 . See Table 6 and text for more details. 